\title{
Virtues that create purpose for ethical leadership : Exemplary principals from Estonia and Finland
}

\section{Eisenschmidt, Eve}

2019-10-02

Eisenschmidt, E , Kuusisto , E , Poom-Valickis , K \& Tirri , K 2019 , ' Virtues that create purpose for ethical leadership : Exemplary principals from Estonia and Finland ' , Journal of beliefs and values, vol. 40 , no. 4 , pp. 433-446 . https://doi.org/10.1080/13617672.2019.1618152

http://hdl.handle.net/10138/326383

https://doi.org/10.1080/13617672.2019.1618152

cc_by_nc

acceptedVersion

Downloaded from Helda, University of Helsinki institutional repository.

This is an electronic reprint of the original article.

This reprint may differ from the original in pagination and typographic detail.

Please cite the original version. 
This is an Accepted Manuscript version of the following article, accepted for publication in Journal of beliefs and values.

Eve Eisenschmidt, Elina Kuusisto, Katrin Poom-Valickis \& Kirsi Tirri (2019) Virtues that create purpose for ethical leadership: Exemplary principals from Estonia and Finland, Journal of Beliefs \& Values, 40:4, 433-446, DOI: 10.1080/13617672.2019.1618152.

It is deposited under the terms of the Creative Commons Attribution-NonCommercial License (http://creativecommons.org/licenses/by-nc/4.0/), which permits non-commercial re-use, distribution, and reproduction in any medium, provided the original work is properly cited. 


\title{
Virtues that create purpose for ethical leadership: Exemplary principals from Estonia and Finland
}

\author{
Eve Eisenschmidt ${ }^{\mathrm{a}^{*}}$, Elina Kuusisto ${ }^{\mathrm{ab}}$, Katrin Poom-Valickis $^{\mathrm{a}}$, Kirsi Tirri $^{\mathrm{cd}}$
}

${ }^{a}$ School of Educational Sciences, Tallinn University, Tallinn, Estonia

${ }^{b}$ Department of Education, University of Humanistic Studies, Utrecht, The Netherlands

${ }^{c}$ Department of Education, University of Helsinki, Helsinki, Finland

${ }^{d}$ Collegium for Advanced Studies, University of Helsinki, Helsinki, Finland

*Correspondence concerning this article should be addressed to

eve.eisenschmidt@tlu.ee

words: 6504

Eve Eiseschmidt is professor of educational management and policy at the School of Educational Sciences at Tallinn University. Her area of research is teacher's professional development, school development and leadership.

Dr Elina Kuusisto works an associate professor at the University of Humanistic Studies, Utrecht, The Netherlands, and as a senior researcher at the University of Tallinn, Estonia. She holds the title of docent at the Faculty of Educational Sciences, the University of Helsinki, Finland. Her academic writings deal with moral, religious and teacher education, with special interest in educating moral sensitivity, purpose in life and growth mindset.

Katrin Poom-Valickis is professor of teacher education at the School of Educational Sciences at Tallinn University. Her area of research is teacher's professional development including identity development, reflection and mentoring.

Kirsi Tirri is a professor and research director at the Helsinki Collegium for Advanced Studies and at the Faculty of Educational Sciences, the University of Helsinki, Finland. Her research interests include school pedagogy, moral and religious education, gifted education, teacher education and cross-cultural studies. 


\title{
Virtues that create purpose for ethical leadership: Exemplary principals from Estonia and Finland
}

\author{
This study investigates how moral virtues create purpose for ethical leadership. \\ Four exemplary principals, two from Estonia and two from Finland, were \\ interviewed to study their perceptions of critical incidents in their work and how \\ moral virtues are manifest in their reflections. The results of qualitative content \\ analysis showed that the critical incidents were related to themselves as \\ principals and to their work with teachers, students and families, and their \\ communities as a whole. The principals demonstrated the virtues of wisdom and \\ knowledge in creating long-term visions for their schools and building the \\ schools for future generations. Other leading virtues were humanity, courage and \\ justice, indicating caring and honesty and involving teachers and parents in \\ decision-making. Based on our study, virtues seem to motivate principals to \\ achieve their desired goals and solve challenging situations in morally sustainable \\ ways. The study confirms that principals' work is value-based, and thus, \\ reflection on moral virtues and the moral dimension of leadership should be \\ integral parts of principals' education.
}

Keywords: principal, moral virtues, critical incident, Estonia, Finland

\section{Introduction}

This study investigates how moral virtues create purpose for ethical leadership. Educational systems and schools face challenges in responding to the expectations of rapidly developing contemporary societies. Comparative studies show that strong leadership is a crucial aspect of managing change and achieving excellence in academic results (Tucker 2011). Principals in Estonia and Finland, the topic of the present study, have considerable freedom in their work: they have the highest degree of autonomy among principals in Europe (OECD 2014) and they are responsible for supporting teachers' professional development and developing pedagogical concepts for their 
schools.

Several studies have addressed what effective principals do (cf. Fullan 2006; Hargreaves 2010), but few have focussed on principals' virtues or the ethical aspects of their work. Research on ethical dilemmas in teaching indicates that teachers are not always aware of the moral impact of their actions (Jackson, Boostrom, and Hansen 1993). We may assume that the same is true of principals, as they too serve as moral educators and role models for their students and teachers, even when they do not consider themselves as such (Hanhimäki and Tirri 2008). However, value-driven leadership in a school is not easy, as leaders have to strike a balance between contradictory demands and expectations. Firstly, they have to take into account the past legacy of the school system as well as its future needs. Secondly, they have to keep in mind, on the one hand, a vision of a future-orientated school system and official regulations and on the other hand, the perceptions and needs of the people involved (teachers, parents and students) (Ball, Maguire, and Braun 2012).

Huber and Muijs (2010) as well other recognised authors in leadership research (cf. Fullan 2006; Hargreaves 2010) point out that principals play a crucial role in improving the quality of education and in changing teaching and learning approaches based on societal expectations and the needs of learners and their families. Leaders should create a vision of what their school should be, a practice that has been regarded as an essential component of successful leadership (Bush and Glover 2014). This is a demanding position, requiring certain competences and personal characteristics, which in turn influence leaders' behaviour and the choices they make. For example, school leaders have to be able to create a community in which students, teachers and parents feel unified. 'Leadership acts as a catalyst' for beneficial effects for others, including the creation of an atmosphere that is favourable to learning (Leithwood, Harris, and 
Hopkins 2008, 28). Principals have the opportunity to create an atmosphere of open communication where a shared vision can take shape and where teachers can continuously improve the quality of teaching and learning, meanwhile building trustful relationships with their colleagues. This kind of collaborative school culture provides a supportive environment that increases teachers' self-efficacy, strengthens their readiness to take responsibility for improving their own teaching (Kohm and Nance 2013), and makes their work more meaningful (Kruse and Louis 2008). School is not only a work environment for teachers, but also an environment for professional growth. School principals are the key figures who create shared values and beliefs among teachers, which then leads to improvement in students' learning (Fullan 2001).

Earlier studies have investigated the moral values, ethical sensitivity and emotional leadership of principals in Finland (Hanhimäki and Tirri 2009; Tirri and Nokelainen 2011), yet in Estonia, these aspects of school leadership have been little researched. Hanhimäki and Tirri (2008) argued that the moral role of a principal is crucial to a school's ethos. Their findings showed that the principals' moral values, such as tolerance, care and equality, guided their work with teachers, students and families. If the principals worked in challenging contexts, such as a school in which the students came from varied socio-economic and cultural backgrounds, it was especially important for the principals to exhibit high moral sensitivity and good communication skills. The principals networked both inside and outside the school to provide the best possible education for their students (ibid.).

Nokelainen and Tirri (2007) have also examined how teachers evaluate principals' emotional leadership. The principals of urban schools were considered to be self-aware and able to keep disruptive emotions and impulses under control, adapt to new challenges, and think positively. The teachers felt that their principals had high 
personal standards, which drove them to seek constant improvements in performance. The principals were also seen as being able to resolve disagreements and monitor parents' and students' satisfaction carefully to ensure that students' and parents' needs were met (Hanhimäki and Tirri 2008; Nokelainen and Tirri 2007). Studies in moral identity suggest that individuals with exceptional moral integrity are able to go beyond their immediate context and personal needs and demonstrate a robust, long-term commitment to ethical causes. Leaders with high morality have a greater awareness of political and social issues and they are also more responsive to societal needs and expectations. They tend to have an optimistic mindset, a coherent set of goals and supportive relationships, all of which help them to identify situations as moral issues (Colby and Damon 1992, 1995).

The concept of 'worldview' can also be used to describe someone's personal views on life and humanity. Such views consist of certain norms and values as well as moral ideas about how people should behave and about what is right and wrong (van der Kooij, de Ruyter, and Miedema 2013, 213). Principals, teachers, children, and parents bring their personal worldviews into the school context, and these views in turn influence their behaviour (ibid. 223).

Brown, Treviño and Harrison (2005) describe ethical leadership as having the dimensions of traits and behaviours. They argued that ethical leadership can be reflected in leadership traits such as integrity, social responsibility, fairness and the willingness to think through the consequences of one's actions. Ethical leaders seek to do the right thing and conduct their lives and leadership roles in an ethical manner (Brown and Treviño 2006). The traits shown in Brown et al. (2005) are close to the moral virtues and character strengths identified by Peterson and Seligman (2004), who have proposed six moral virtues that capture historical and current discussion on the topic: (1) Wisdom 
and knowledge refer to strengths such as creativity, curiosity, love of learning, perspective and open-mindedness in terms of judgement and critical thinking. (2) Courage means bravery, persistence, vitality, integrity, authenticity and honesty. (3) Humanity stands for love, kindness, care and social intelligence. (4) Justice signifies social responsibility, loyalty, teamwork, fairness and leadership (i.e. following through on tasks while keeping good relations). (5) Temperance covers forgiveness and mercy, humility and modesty, prudence and self-regulation. (6) Transcendence refers to an appreciation of beauty and excellence, gratitude, hope, humour and spirituality. Peterson and Seligman's (2004) classification has been widely acknowledged and frequently utilized; according to Google Scholar, over 7,500 studies have cited it. The classification has been developed through rigorous review of theoretical, historical and empirical investigations. It presents virtues as the core characteristics of the values that moral philosophers and religious thinkers have found to be universal. The character strengths define concretely the contents of the more abstract virtues, and thus, the classification provides a comprehensive framework that is suitable for educational contexts, such as the present study.

The aim of our research is to investigate how moral virtues create purpose in principals' work. In our research, we explore (1) the kinds of critical incidents that can be found in school principals' perceptions of their work and (2) the kinds of moral virtues principals display in their reflections.

\section{Data and methods}

\section{Participants}

The participants in our study were four school principals: two from Estonia (Kadri and 
Raul) and two from Finland (Jaakko and Timo). All principals' names are pseudonyms. The principals were chosen based on a purposeful sampling with the following criteria: all four are respected leaders and committed to developing their schools; all work closely with their national universities by contributing to initial teacher education and research; and all participate and advocate in-service education of teachers and other principals and vice-principals. Although in both countries, principals mainly have master's degrees, one of our criteria was to find one principal in each country with a doctoral degree. We also wanted school leaders who work in multicultural contexts.

All four participating principals have endeavoured to develop themselves professionally. For example, Kadri and Timo have doctoral degrees in education, which is still rare among school principals. Raul holds two master's degrees, one in teacher education and another in educational management. The Estonian principals were younger (40 and 44 years) than the Finnish principals (52 and 49 years) and less experienced than their Finnish counterparts: 9 and 7 years compared to their Finnish colleagues' 11 and 23 years of principal experience (see Table 1).

Table 1 approximately here

\section{Data collection}

Two researchers from each country gathered the data (every researcher interviewed one principal) using thematic qualitative interviews (Kallio, Pietilä, Johnson, and Kangasniemi 2016) during May 2018. The interviews lasted from one to one and a half hours. Four themes were discussed in the interviews: the interviewee as a principal, pedagogical interaction (including encountering diversities), developing a curriculum, and pedagogical leadership. The principals were asked to give examples and describe 
critical incidents that were the most challenging, important or difficult during their career as school principals and that were related to above-mentioned issues. In addition, the interviewees were asked to give background information about their schools.

\section{Data analysis}

The Estonian researchers analysed the interviews of the Estonian principals, and the Finnish researchers analysed the interviews of the Finnish principals. After reading the principals' interviews, each researcher identified critical incidents in the principals' work that illustrated 'a situation where the purpose or intent of the act seems fairly clear to the observer and where its consequences are sufficiently definite to leave little doubt concerning its effects' (Flanagan 1953, 327). Critical incidents as tools of qualitative data analysis supports Denzin's (1989) claim that lives are constructed and turned around by significant events. Critical incidents in this study are defined as issues or situations in the principals' work that generated ethical reflection on moral virtues.

The core of every critical incident researchers identified was condensed into a few sentences, following the conventions of qualitative content analysis (Elo and Kyngäs 2008). Two examples of the condensed incidents can be found in Table 2. Next, the framework developed by Hanhimäki and Tirri (2009) was used as a deductive analytical tool (Elo and Kyngäs 2008) in order to categorise the contents of the critical incidents. In addition, the researchers inductively created new subcategories for those incidents that did not fit into the subcategories proposed by Hanhimäki and Tirri (2009) (i.e. professional development as a leader, teachers' collaboration, parental involvement, curriculum, external networking, physical school environment).

Moral virtues related to the critical incidents were analysed deductively by utilising Peterson and Seligman's (2004) classification of moral virtues as main categories and character strengths as subcategories. The researchers identified which 
virtue was manifested in each critical incident. For example, Kadri was describing how she had admitted her communication mistakes to her teachers, yet she still wanted to communicate difficult issues (see Table 2). This example illustrates courage as her moral virtue, the main category, and honesty as her character strength, the subcategory.

Table 2 approximately here

In the initial phase of analysis, each researcher checked the reliability of the coding by comparing their analysis with their research partner in the same country. During mutual discussions some of the themes were dropped and others prioritised. In the final stage, one researcher from Estonia and one from Finland checked the coding and discussed the similarities and differences between the Estonian and the Finnish data. All disagreements were discussed until the researchers reached a common interpretation of the themes selected.

For example, variance in some subcategories, particularly in interpreting the differences between critical incidents related to teachers' collaboration and supporting teachers, was found to be challenging because of the similar wording, but after specifying the meaning of both subcategories, a unanimous solution was reached.

\section{Results}

Seventy-five critical incidents related to principals' work were identified. Each incident was analysed from the perspective of content and moral virtue. The results of the analysis are presented in Tables 3 and 4. 
Table 3 approximately here

The content of the critical incidents concerned the principals themselves $(f=18)$, specifically their professional development during their career, and the principals' reflections on their role as being like that of a diplomat or the CEO of a large company while having the spirit of an entrepreneur or athlete.

Critical incidents in working with teachers $(f=17)$ emphasised creating shared understanding and opportunities for mutual collaboration among teachers as well as supporting teachers in their work and professional development. The principals expressed the need for a trusting and open atmosphere in which all teachers could be heard.

In the category of working with students and families $(f=14)$, critical incidents related to diversity emerged in schools where the multicultural and socio-economic backgrounds of the students and their families needed to be considered. Incidents regarding parental involvement indicated the need to create trustful relations and engage in mutual communication, in a way that parents were informed of their children' learning difficulties and willing to collaborate with teachers in the interest of their children's education.

Critical incidents related to working with the community $(f=26)$ were the most often discussed content in the interviews. The principals reflected on the implementation of the curriculum and proposed innovative ideas for its execution. They endeavoured to create a school culture that supported sustainable change and physical school environments adapted to contemporary learning theories. The principals demonstrated that they were active in external networks, in working with the local 
communities, and in co-operating with their ministries of education and universities. The principals also addressed collaboration with other school principals, participation in the in-service training of teachers, and supporting beginner leaders.

Table 4 approximately here

Almost half of the moral virtues exhibited in the critical incidents were related to wisdom and knowledge $(f=36)$. The principals brought many different perspectives to their work, which served as visions of how they wanted to develop mutual trust, distributed leadership and good relationships in the school community as a whole, especially the idea of taking students' individual needs into account. They exhibited critical thinking in their reflections on current societal demands and trends as well as in their collaboration with actors outside the school's daily life. The principals' love of learning was evident in their stories that illustrated their interest in a holistic development of themselves as professionals.

The principals demonstrated the virtue of humanity $(f=13)$ by showing their concern for their teachers, students and families, and the whole school community as well as their willingness to collaborate with neighbouring actors outside the immediate school environment. Social intelligence was evident in how the principals described solving challenging situations with students and parents.

Critical incidents indicated the virtue of courage $(f=11)$, manifested in the principals' persistence in the face of challenges and setbacks, their refusal to give up, and their willingness to learn from such incidents. They acknowledged their faults honestly, both in the interviews and in the descriptions of their mistakes, and thereby 
built an environment of trust among their teachers. In circumstances involving violence on the part of parents and/or students, they demonstrated bravery in their actions to resolve and defuse these situations.

The virtues that occurred the least often in the data were justice, transcendence and temperance. The principals served justice $(f=7)$ in the way they engaged everyone in the school community to share their ideas and found the means to do this even in large schools. Transcendence $(f=7)$ refers to incidents in which the principals had either given or received positive feedback on their schools, appeared to be highly trusted, had acknowledged the good work of their teachers or how their strove to make every encounter meaningful, if only for a brief moment. Temperance $(f=3)$ refers to modesty and humility, evident, for example, in how one principal did not push herself into a leadership position or how, after a long and impressive career, one principal wanted to be remembered as a good person and a gentleman.

In the next section, the critical incidents are explained from the perspective of each of the four principals. Every principal's story will focus on the categories of the critical incidents and the moral virtues that were most in evidence in their interviews.

\section{Kadri: Courage to become a principal}

Kadri was the principal of a school where she had earlier been a teacher. Kadri's colleagues had encouraged her to apply for the position, as they had seen her potential. The change of position was difficult, but Kadri showed courage and especially persistence in creating her vision and becoming a trusted principal, although she had no preparation or mentoring. Kadri admitted that she had made many mistakes in communicating with teachers at the beginning of her career as a principal. Nevertheless, she had understood that all decisions should be made by giving priority to students' 
needs and development, even if that meant confrontations with teachers and parents.

Kadri said that her ultimate vision for her school was to create a caring atmosphere. She cared for her students so much that she once drove to another city to meet a student's parent who had not shown up for her scheduled appointment:

I agreed on several appointments with a [single] parent who never showed up. Actually, she [mother] lived in another town and she had no [after-school] care for her child. I decided that I had to meet her face-to-face to find a solution for the situation. So I decided to make the 100-kilometre drive, even though I wasn't sure that I would have the chance to meet her. (Kadri, Est)

Kadri also demonstrated caring in her support of her teachers, even helping them to solve personal problems and providing extra support to young teachers to prevent their leaving school or suffering burnout. She emphasised the importance of good communication to ensure that everyone is involved and knows what is happening at the school. Kadri also said that her intention has been to cultivate shared understanding and values about teaching and learning, where the focus is on every student's development and the joy of learning. She created learning communities with teachers from different school levels so that everyone would work together. In this way, trust in and respect for each other's competences has been developed in her school. Thus, it can be stated that Kadri demonstrated courage and care by not giving up on her principles and by not letting down those with and for whom she was working.

\section{Raul: Justice in working with teachers}

Raul was a principal in a growing multicultural school in a low socio-economic area. Raul had developed his pedagogical competence by working as a teacher in a preschool, a vocational school and a sports school. During his teacher education, Raul took elective 
courses in economics.

In Raul's vision, a principal was an organiser, a person who should have an entrepreneurial attitude and find new ways to develop a school. He saw leaders as athletes who need to achieve the best results; for them, there is always room for improvement:

I walk around with my eyes open [looking to see] whether there is something interesting. I cannot pass up [an opportunity]. Rather there is always the question of how to let something go. If things succeed, then that is what inspires you. [...] I like to draw parallels with sports; I guess I have a kind of sportsman's spirit [as a principal]. (Raul, Est)

In his vision, Raul emphasised the involvement of parents, as he believes that everyone should know what is happening in his school and thinks that all critical incidents should be communicated and explained openly and honestly. For him, the most valuable aspect of his work was the individual meetings with parents, as those have resulted in the best solutions for the students. Raul also arranged parents' meetings and events for families where students could demonstrate what they do at school.

Raul considered supporting teachers, their well-being and internal relations very important. He emphasised justice with regards to teachers' workload and possibilities for their professional development. He highlighted that it is important to recognise teachers' good work, offer praise and even give financial bonuses to those who take on more responsibilities and tasks. Raul was seeking opportunities to arrange social events and recreation for the teachers.

Raul had a clear vision of a principal's role and perspectives. He advocated justice in motivating and working with his teachers. 


\section{Timo: Social intelligence in encountering challenging students}

Timo has been a principal his whole career and had written a doctoral dissertation on leadership. In his view, a principal should be a visionary who adopts a long-term perspective on education and who sees students' futures as of central concern. Timo demonstrated critical thinking when he reflected on the discrepancy between the requirements of the curriculum and the school reality and how, for example the digital revolution, inclusive education and phenomenon teaching are all pedagogically and practically challenging to implement. Timo commented on ICT issues by saying that:

Not all applications are working; sometimes it is a waste of time. You need to discuss the advantages and disadvantages. If it is a failure, everybody is frustrated. (Timo, Fin)

Timo talked about diversity among families and students, and how students from different socio-economic backgrounds and nationalities should be as well-educated as the mainstream students. He illustrated the virtue of humanity, especially in the form of social intelligence, when he advocated behaviour in which he as the school leader adjusts and finds a level and mode of communication which parents and students understand and feel comfortable with. Timo wanted to put families at ease by wearing casual clothing so that he would not be intimidating in his role as principal. He also developed what he called 'Donald Duck therapy' to deal with restless students:

I remember one kid. He was behaving so badly and violently that his school days always had to be curtailed. One time, when his teacher was completely worn out by this student, I brought the boy to my office. I gave him a Kunto magazine [a Finnish magazine about a healthy lifestyle] and said, 'Read this. I have to work now. I do not have time to talk to you.' I continued working and [I suddenly realised that] the kid had disappeared. I went looking for him and 
found him in his class. I said, 'Why are you here?' He answered, 'Well, I've already calmed down. I can continue my studies.' That's when we came up with Donald Duck therapy. I bought some Donald Duck magazines and every time that [the student] felt that he was losing it, he came to my office to read Donald Duck for a bit and then he went back to the class. We did not have to interrupt his school days anymore. [...] A harsh and strict principal did not solve the problem: Donald Duck therapy did. (Timo, Fin)

It seems that social intelligence was one of Timo's strengths as a principal.

\section{Jaakko: Caring in creating a school community}

Jaakko was the principal of a basic education school in a multicultural and low socioeconomic area. At the time of the interview, the school was undergoing major disruptions. One of these was administrative: previously, the elementary school (grades 1-6) and the lower secondary school (grades 7-9) had been independent of one another, each with its own principal, schedules, and programs; but then, the nine grades had been merged to form a unified, basic education school. The second source of major turmoil involved the school building. Mould in the building was causing breathing problems in the students. Jaakko had to evacuate the classrooms and place the students in temporary barracks while reparations of the school building were underway.

Jaakko had a clear vision of how he wanted to develop the school culture. He wanted the whole school to be on the same timetable, which would give teachers the opportunity to meet in the teachers' lounge for discussion and make plans together. $\mathrm{He}$ wanted to create a close community where different school levels could be seen as a continuum rather than as a set of separated stages. Jaakko's vision was to 'break down 
the walls' between the class teachers and the subject teachers at the elementary and secondary levels and use every teacher's qualifications in the best possible way:

We have a lot of teachers who have double qualifications [class teachers with subject teacher education in one or more subjects and vice versa] and these competences should be utilised in this school. Also students' knowledge should be acknowledged. If a teacher has been instructing a student since the 3rd grade and then he or she hits puberty, there is this teacher who has known that student for several years. Then the [student's] problems can be solved totally differently. (Jaakko, Fin)

For Jaakko, building a tight community of teachers meant a process that helps teachers to support students' learning holistically while the students navigate puberty.

Jaakko displayed humanity in genuinely caring for his school and for the area where the school was located. Together with the providers of children's services and other stakeholders in the neighbourhood, he sought solutions to problems, which the school could not solve alone, such as generational poverty, alcoholism and drug abuse. For example, there were many seven-year-old, first-grade students who were not socially or emotionally ready to start school because of parental problems. Moreover, Jaakko expressed concern at the increasing rates of immigrants in the area, a situation that can lead to the formation of ghettos, which make integration into Finnish society challenging. In Jaakko's school, about 50 per cent of the students had an immigrant background. In effect, Jaakko illustrated vision and caring in leading the reparations of the school building, shepherding the teachers through stressful changes, and navigating the challenges of a school in a multicultural and low income socio-economic area. 


\section{Concluding remarks}

By using interviews with Estonian and Finnish school principals $(\mathrm{N}=4)$, this study has investigated how moral virtues create purpose in the work of school principals. The researchers explored perceptions of critical incidents in the principals' work and the moral virtues the principals showed in reflecting on their roles. The study contributes to the knowledge of ethical leadership in schools with data from two high-achieving educational systems in Europe.

The principals in this study can be said to exemplify ethical leadership, as all of them displayed moral virtues in critical incidents, whether those incidents were related to themselves as principals, or to working with their teachers, working with students and families or working with the whole community.

The principals demonstrated high aspirations towards the virtues of wisdom and knowledge in creating long-term visions for their schools or, as some of our principals put it, they were building their schools for future generations, always taking into consideration what was best for their students. All the principals in this study showed that they have established priorities, and they described clear aims related to the teaching curriculum, although they found it challenging to obtain the necessary resources for meaningful school improvements. Our findings imply that ethical school principals have a clear vision for developing their institutions as learning communities that offer support to teachers, provide them with time to meet and make plans and adopt innovative pedagogical practices.

The principals not only provided perspective and vision for their school communities, but also showed their own love of learning. In line with the findings of Hanhimäki and Tirri (2009), ethically sensitive leaders are committed to their work and to their growth as leaders and human beings. The beliefs and values in someone's 
personal worldview are among the sources used to reflecting on what to believe and what to strive for and either consciously or subconsciously can be a stimulant to act and perceive life in a certain way (van der Kooij, et al. 2013, 221). Whereas ethical values are concerned with the broad theme of 'the good life', moral values can be restricted to values related to other people's well-being (ibid., 214).

Ethical leaders understand that the role of a leader is constantly changing and that leaders have to develop their competences according the context, the school curriculum, teachers' work, and students' needs. Today, educational systems face the challenges of globalisation, and classrooms are more and more multicultural. Our exemplary principals highlighted the need to deal with diversity and consider the individual needs of students to ensure equity in education. Showing humanity and caring in dealing with family problems, along with diversity and multiculturalism, were among the main themes that emerged from the interviews. The principals manifested the moral virtue of justice when they emphasised that in the context of inclusive education, the involvement of parents is very important, and everyone needs to be heard in decision-making processes. The principals also acknowledged their responsibilities to the community around the school. They were active in external networks and they cooperated with their local communities. Furthermore, they were active at higher levels of the educational system by cooperating with ministries of education and proposing innovative ideas, or by being involved in principals' networks, collaborating with other school leaders and mentoring beginner leaders.

This study broadens the understanding of school principals' morality, especially in the Estonian context, where the topic had not been investigated previously. The results indicate that in high-achieving educational systems like Estonian and Finnish, exemplary principals like those presented here seem to act based on similar virtues. The 
present study confirms that principals' work is value-based, and thus reflection on moral virtues and the moral dimension of leadership should be integral parts of school principals' education.

The limitations of this study can be seen as possibilities for future research. It would be important to collect data from different kinds of principals and with larger sample sizes to analyse what kinds of virtues guide their work and how. Based on our research, virtues seem to motivate principals to move towards desired goals and solve challenging situations in a morally sustainable way. We may conclude that moral virtues create purpose for principals' work.

\section{Acknowledgement}

This research was supported by „TU TEE - Tallinn University as a promoter of intelligent lifestyle“ (nr 2014-2020.4.01.16-0033).

\section{References}

Ball, S. J., M. Maguire, and A. Braun. 2012. “Doing enactment research. In How schools do policy: Policy enactments in secondary schools." London: Routledge: Taylor \& Francis Group.

Brown, M. E., and L. K. Treviño. 2006. "Ethical leadership: A review and future directions." The Leadership Quarterly 17: 595-616.

Brown, M. E., L. K. Treviño, and D. A. Harrison. 2005. "Ethical leadership: A social learning perspective for construct development and testing." Organizational Behaviour and Human Decision Processes 97: 117-134.

Bush, T., and D. Glover. 2014. "School leadership models: What do we know?" School Leadership \& Management 34 (5): 553-571.

Colby, A., and W. Damon. 1992. Some do care: Contemporary lives of moral commitment. New York: Free Press. 
Colby, A., and W. Damon. 1995. "The development of extraordinary commitment." In Morality in Everyday Life: Developmental perspectives, edited by M. Killen and D. Hart, 343-369. New York: Cambridge University Press.

Denzin, N. 1989. Interpretive biography. NewBury Park, CA: Sage Publications.

Flanagan, J. 1953. The critical incident method. Pittsburgh, PA: American Institute for Research and University of Pittsburgh.

Hanhimäki, E., and K. Tirri. 2008. "The moral role and characteristics of Finnish urban schools principals." Journal of Research in Character Education 6: 53-65.

Hanhimäki, E., and K. Tirri. 2009. "Education for ethically sensitive teaching in critical incidents at school." Journal of Education for Teaching 35 (2): 107-121.

Elo, S., and H. Kyngäs. 2008. "The qualitative content analysis process." Journal of Advanced Nursing 62: 107-115.

Fullan, M. 2001. Leading in a Culture of Change. San Francisco: Jossey Bass.

Fullan, M. 2006. Change theory. A force for school improvement. Seminar Series Paper 157. Australia: Centre for Strategic Education.

Hargreaves, D. 2010. Creating a Self-Improving School System. Nottingham: National College.

Hoch, J.E., W.H. Bommer, H., J. Dulebohn, and D. Wu. 2016. "Do Ethical, Authentic, and Servant Leadership Explain Variance Above and Beyond Transformational Leadership? A Meta-Analysis.” Journal of Management 44 (2): 501-529.

Huber, S., and D. Muijs. 2010. "School Leadership Effectiveness: The Growing Insight in the Importance of School Leadership for the Quality and Development of Schools and their Pupils." In International Perspectives on School Leadership, edited by S. Huber, 57-77. Oxford: Springer.

Jackson, P. W., R. Boostrom, and D. Hansen. 1993. The moral life of schools. San Francisco: Jossey-Bass.

Kallio, H., A.-M. Pietilä, M. Johnson, and M. Kangasniemi. 2016. "Systematic methodological review: developing a framework for a qualitative semistructured interview guide." Journal of Advanced Nursing 72 (12): 2954-2965.

Kohm, B., and B. Nance. 2013. "Creating Collaborative Cultures.” Educational leadership 67 (2): 67-72.

Kruse, S. D., and K. Louis. 2008. Building Strong School Cultures: A Guide to Leading Change. A Joint Publication. 
Leithwood, K., A. Harris, and D. Hopkins. 2008. "Seven Strong Claims About Successful School Leadership.” School leadership and management 28 (1): 27 42.

Nokelainen, P., and K. Tirri. 2007. "Empirical investigation of Finnish school principals' emotional leadership competencies." In Ammatillinen kasvu. [Professional growth.] Festschrift for Pekka Ruohotie edited by S. Saari and T. Varis, 424-38. Finland: OKKA.

OECD. 2014. "TALIS 2013 Results: An International Perspective on Teaching and Learning.” OECD Publishing. http://dx.doi.org/10.1787/9789264196261-en

Peterson, C., and M. E. P. Seligman. 2004. Character strengths and virtues: A handbook and classification. New York: Oxford University Press.

Tirri, K., and P. Nokelainen. 2011. Measuring Multiple Intelligences and Moral Sensitivities in Education. Moral Development and Citizenship Education. Rotterdam: Sense Publisher.

Tucker, M. S., ed. 2011. Surpassing Shanghai: An Agenda for American Education Built on the World's Leading Systems. Cambridge, Massachusetts: Harvard Education Press.

Van der Kooij, J. C., D. J. de Ruyter, and S. Miedema. 2013. ““'Worldview”: the Meaning of the Concept and the Impact on Religious Education." Religious Education 108 (2): 210-228. 
Table 1. Background information about the principals and their schools

\begin{tabular}{|c|c|c|c|c|}
\hline & Raul & Kadri & Jaakko & Timo \\
\hline Nationality & Estonian & Estonian & Finnish & Finnish \\
\hline Gender & Male & Female & Male & Male \\
\hline Age & 40 & 44 & 52 & 49 \\
\hline Education & $\begin{array}{l}2 \text { MA degrees: } \\
\text { MA (teacher } \\
\text { education), MA } \\
\text { (educational } \\
\text { management) }\end{array}$ & $\begin{array}{l}\text { PhD in } \\
\text { education, part- } \\
\text { time work in } \\
\text { university } \\
\text { teacher training } \\
\text { programme }\end{array}$ & MA (Education) & $\begin{array}{l}\text { PhD in } \\
\text { education, title } \\
\text { of university } \\
\text { docent }\end{array}$ \\
\hline $\begin{array}{l}\text { Work } \\
\text { experience as a } \\
\text { principal }\end{array}$ & 9 & 7 & $\begin{array}{l}11 \\
\text { (earlier } 14 \text { years } \\
\text { as a vice- } \\
\text { principal) }\end{array}$ & 23 \\
\hline $\begin{array}{l}\text { Educational } \\
\text { level of the } \\
\text { school which } \\
\text { the principal } \\
\text { was heading }\end{array}$ & $\begin{array}{l}\text { Basic education } \\
\text { (grades 1-9) and } \\
\text { general upper } \\
\text { secondary } \\
\text { education } \\
\text { (grades 10-12) }\end{array}$ & $\begin{array}{l}\text { Basic education } \\
\text { (grades 1-9) }\end{array}$ & $\begin{array}{l}\text { Basic education } \\
\text { (grades 1-9) }\end{array}$ & $\begin{array}{l}\text { Basic education } \\
\text { (grades 1-9) and } \\
\text { general upper } \\
\text { secondary } \\
\text { education } \\
\text { (grades 10-12) }\end{array}$ \\
\hline $\begin{array}{l}\text { School size and } \\
\text { context }\end{array}$ & $\begin{array}{l}\text { ca } 900 \text { students } \\
\text { in multicultural } \\
\text { and low SES } \\
\text { area }\end{array}$ & $\begin{array}{l}\text { ca } 908 \text { students, } \\
\text { average SES } \\
\text { area }\end{array}$ & $\begin{array}{l}\text { ca } 1,000 \\
\text { students, } \\
\text { in multicultural } \\
\text { and low SES } \\
\text { area }\end{array}$ & $\begin{array}{l}\text { ca } 1,500 \\
\text { students, } \\
\text { average and } \\
\text { high SES area }\end{array}$ \\
\hline School location & Tallinn & Tartu & Helsinki & Helsinki \\
\hline
\end{tabular}


Table 2. Examples of the data analysis and categorisation

\begin{tabular}{|c|c|c|}
\hline Critical incident $\quad$ (condensed) & $\begin{array}{l}\text { Content of critical } \\
\text { incident } \\
\text { Category } \\
\text { Sub-category }\end{array}$ & $\begin{array}{l}\text { Moral virtue exhibited in } \\
\text { the critical incident } \\
\text { Category } \\
\text { Sub-category }\end{array}$ \\
\hline $\begin{array}{l}\text { The most difficult thing was to tell } \\
\text { my former colleagues that they } \\
\text { needed to change their teaching } \\
\text { practices. I made communication } \\
\text { mistakes, but I gave priority to } \\
\text { students' interests and learned to } \\
\text { get my message across so that it } \\
\text { didn't hurt the teachers (Kadri, } \\
\text { Est). }\end{array}$ & $\begin{array}{l}\text { I as the principal } \\
\text { Professional } \\
\text { development } \\
\text { Explanation: } \\
\text { principal describes } \\
\text { her learning process }\end{array}$ & $\begin{array}{l}\text { Courage } \\
\text { Honesty } \\
\text { Explanation: } \\
\text { The need to say critical } \\
\text { things to former colleagues } \\
\text { and admit making mistakes, } \\
\text { which shows honesty and } \\
\text { manifests courage }\end{array}$ \\
\hline
\end{tabular}


Table 3. Categories of critical incidents by principal

\begin{tabular}{|l|l|l|l|l|l|}
\hline Content of critical incidents & $\begin{array}{l}\text { Raul } \\
\text { Est } \\
\mathrm{f}\end{array}$ & $\begin{array}{l}\text { Kadri } \\
\text { Est } \\
\mathrm{f}\end{array}$ & $\begin{array}{l}\text { Jaakko } \\
\text { Fin } \\
\mathrm{f}\end{array}$ & $\begin{array}{l}\text { Timo } \\
\text { Fin } \\
\mathrm{f}\end{array}$ & In total (Est/Fin) \\
\hline $\begin{array}{l}\text { I as the principal } \\
\text { Sub-categories: role of the } \\
\text { principal, professional } \\
\text { development }\end{array}$ & 5 & 7 & 2 & 4 & $18(12 / 6)$ \\
\hline $\begin{array}{l}\text { Working with teachers } \\
\text { Sub-categories: teachers } \\
\text { collaboration, supporting } \\
\text { teachers }\end{array}$ & 5 & 6 & 5 & 1 & $17(11 / 6)$ \\
\hline $\begin{array}{l}\text { Working with students and } \\
\text { families } \\
\text { Sub-categories: diversities, } \\
\text { parental involvement }\end{array}$ & 4 & 3 & 2 & 5 & $14(7 / 7)$ \\
\hline $\begin{array}{l}\text { Working with the community } \\
\text { Sub-categories: curriculum, } \\
\text { school culture, external } \\
\text { networking, physical school } \\
\text { environment }\end{array}$ & 5 & 5 & 9 & 7 & $26(10 / 16)$ \\
\hline \begin{tabular}{l} 
Totals \\
\hline
\end{tabular} & 19 & 21 & 18 & 17 & $75(40 / 35)$ \\
\hline
\end{tabular}


Table 4. The principals' moral virtues

\begin{tabular}{|l|l|l|l|l|l|}
\hline $\begin{array}{l}\text { Moral virtues exhibited in } \\
\text { critical incidents }\end{array}$ & $\begin{array}{l}\text { Raul } \\
\text { Est } \\
\mathrm{f}\end{array}$ & $\begin{array}{l}\text { Kadri } \\
\text { Est } \\
\mathrm{f}\end{array}$ & $\begin{array}{l}\text { Jaakko } \\
\text { Fin } \\
\mathrm{f}\end{array}$ & $\begin{array}{l}\text { Timo } \\
\text { Fin } \\
\mathrm{f}\end{array}$ & $\begin{array}{c}\text { In total } \\
\text { (Est/Fin) } \\
\mathrm{f}\end{array}$ \\
\hline $\begin{array}{l}\text { Wisdom and knowledge } \\
\text { Sub-categories: perspective } \\
\text { [vision], critical thinking, love } \\
\text { of learning }\end{array}$ & 10 & 6 & 9 & 8 & $36(19 / 17)$ \\
\hline $\begin{array}{l}\text { Humanity } \\
\text { Sub-categories: caring } \\
\text { concern, social intelligence }\end{array}$ & 2 & 3 & 4 & 4 & $13(5 / 8)$ \\
\hline $\begin{array}{l}\text { Courage } \\
\text { Sub-categories: persistence, } \\
\text { honesty, bravery }\end{array}$ & 0 & 6 & 3 & 2 & $11(6 / 5)$ \\
\hline Justice & 2 & 2 & 1 & 2 & $7(4 / 3)$ \\
\hline Transcendence & 1 & 1 & 0 & 1 & $3(2 / 1)$ \\
\hline Temperance & 21 & 18 & 17 & $75(40 / 35)$ \\
\hline Totals & 2 & 1 & 0 & $7(6 / 1)$ \\
\hline
\end{tabular}

